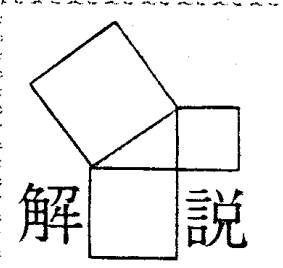

\title{
国産マシニングセンタの現状 需給動向と技術評価
}

Present Status of Japanese Machining Center - Supply \& Demand Trend and Technical Evaluation-

\section{大 $\underset{\substack{\text { 高 } \\ \text { Yoshio OTAKA }}}{\text { 義 }}$ 穂*}

Key Words: Manufacturing Technology, Cutting, Machine Tool, Machining Center, Technology Assessment

\section{1.まえがき}

1952 年にアメリカにおいて開発された数値制 御（NC）技術は金属部品の加工技術及ご后作機 械の態様に大きな変革をもたらした。マシニング センタの出現はその最たるものといえるである う.

1958 年に Kearney-Trecker 社（アメリカ）か ら発表された機械一工具の自動交換装置 (ATC) を有し, 従来のフライス盤, 中ぐり盤, ボール盤等の各機能を併せ持ち，多種類の加工工 程を自動的に行えるマシニングセンタ一一はそれ までの工作機械の概念を変えた全く新しい機械と して世界各国に広まった(1).

わが国でも昭和 40 年代に入って開発・生産が進 み，制御技術，センサの高度化，工作物自動交換 機能の開発などと相まって, FMC（フレキシブ ル加エセル）へ，さらにFMS（フレキシブル生 産システム), FA（ファクトリオートメーショ ン）の主要機械としてマシニングセンタ沽機械工 業に大きなインパクトを与えていることは周知の とおりである。

今から 20 年程前, アメリカ・シカゴで開発され た工作機械展を見学したある設計技術者が，「将 来工作機械住旋盤と研削盤と, そしてマシニング センタさえあればよいという時代になるのではな いか」と語ったことがある。事実，昭和 59 年の

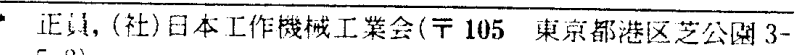
5-8).

日本機械学会婄第89卷第807年
わが国工作機械の生産実績をみると，この 3 機種 で全体の約 $2 / 3$ に当たる $63 \%$ に達しており，マ シニングセンタだけで $24 \%$ を占めている(図 $1)^{(2)}$. 放電加工機や尃用機など特殊なものを除 けば，角物部品加工の主役は完全にマシニングセ ンタに移っていることを示している。

このように開発されてから 20 年余り，マシニ ングセンタは著しい成長を遂げたが，この間ユー ザのニーズにより，また省力化，無人化，システ ム化が進むにつれ，様々な形態のマシニングセン 夕が発表されてきた。本稿は工作機械工業の中で 特に成長著しい日本のマシニングセンタを取り上 げ,

（1）現在日本で生産されているマシニングセン 夕にはどのような種類があるか。

（2）それらはどの程度生産され, 輸出されてい るか。

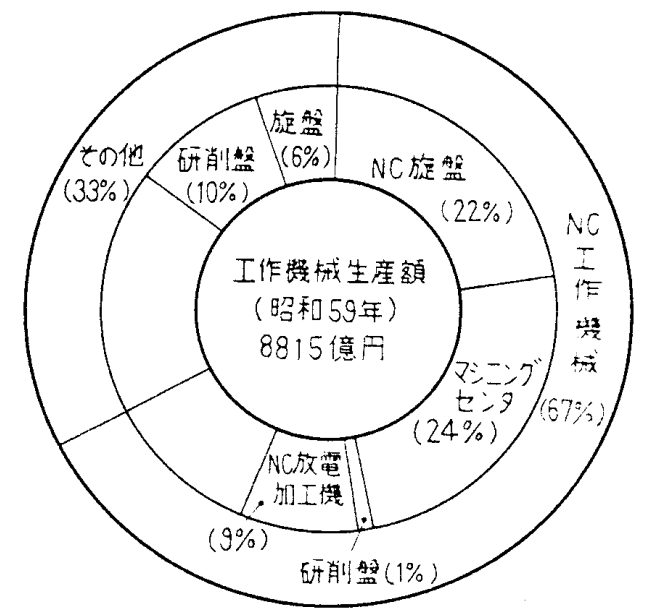

図 1 工作機械生麾額機種別棈成 畹和61 年 2 月 


大高義穗

（3）それらのマシニングセンタ流世界市場でど

の上うに評洒きれているか, 課題は何か. 等について明らかにしようとするものである。

\section{2. マシニングセンタの種類}

マシニングセンタが普及しはじめたころ，命の 概念法次のようであった。

(a) 数值制御工作機械であること

(b) フライス削り，穴あけ，中ぐり等多種類の

作業を自動的に行えること

(c) 工具の自動交換機能を有寸ること

(d) 多面加工ができること

このような概念からマシニングセンタは本来, 角 物部品加工用の割出しテーブルを有する横主軸の

機械を意味していた。

しかし，その後，薄物（板状）部品や金型加工 に適した立て主軸機や，旋削を主体とをた王作物 回転形のマシニングセンタ（ターニングセンタ） 等が出現し，その種類は多岐にわたっている。

図 2 はマシニングセンタの種類をそれぞれ元の 工作機械との関連で示したものである(3)。

（1）横軸マシニングセンタ 横フライス盤， 横中ぐり盤から発展したものが多く，世界最初の マシニングセンタといわれている KearneyTrecker 社の機械をはじめ，初期のマシニング
表 1 昭和 59 年のマシニングセンタ生産

\begin{tabular}{|c|c|c|}
\hline 形 & 台 & 金再晋) \\
\hline $\begin{aligned} \text { 立こ 軸 } & \text { 形 } \\
\text { 前传又トローク } & <500 \mathrm{~mm} \\
\text { " } & \geqq 500 \mathrm{~mm}\end{aligned}$ & $\begin{array}{l}6589 \\
(4225) \\
(2364)\end{array}$ & $\begin{array}{l}107566 \\
(60501) \\
(47065)\end{array}$ \\
\hline 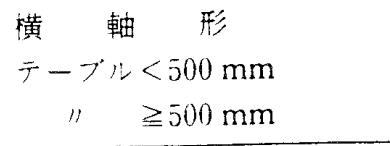 & $\begin{array}{l}2567 \\
(820) \\
(1747)\end{array}$ & $\begin{array}{l}76275 \\
(15582) \\
(60693)\end{array}$ \\
\hline 形 & 1017 & 26103 \\
\hline 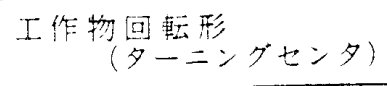 & 79 & 3112 \\
\hline 合 & 10252 & 213056 \\
\hline
\end{tabular}

センタの主流である。

(2) 立て軸マシニングセンタ横軸より漣れ て出現したが，关の作業性の良さや，金型加工に 適する等から現在で法生産台数で横軸の 2 倍程度 になっている，立てフライス盤，立て中ぐり盤か ら発展したもので，ボール盤に軽フライス加工機 能を付加したミニマシニングセンタも多く見られ ろ.

(3) 門形マシニングセンタ比較的大形の工. 作物用として，立て中ぐり篮やプラノミラー等か ら発展したもので，最近では主軸を立て・横両方 に使えるようにし，工作機械のベッドやコラム等 の大物構造物の 5 面を一度の取付けで加工可能

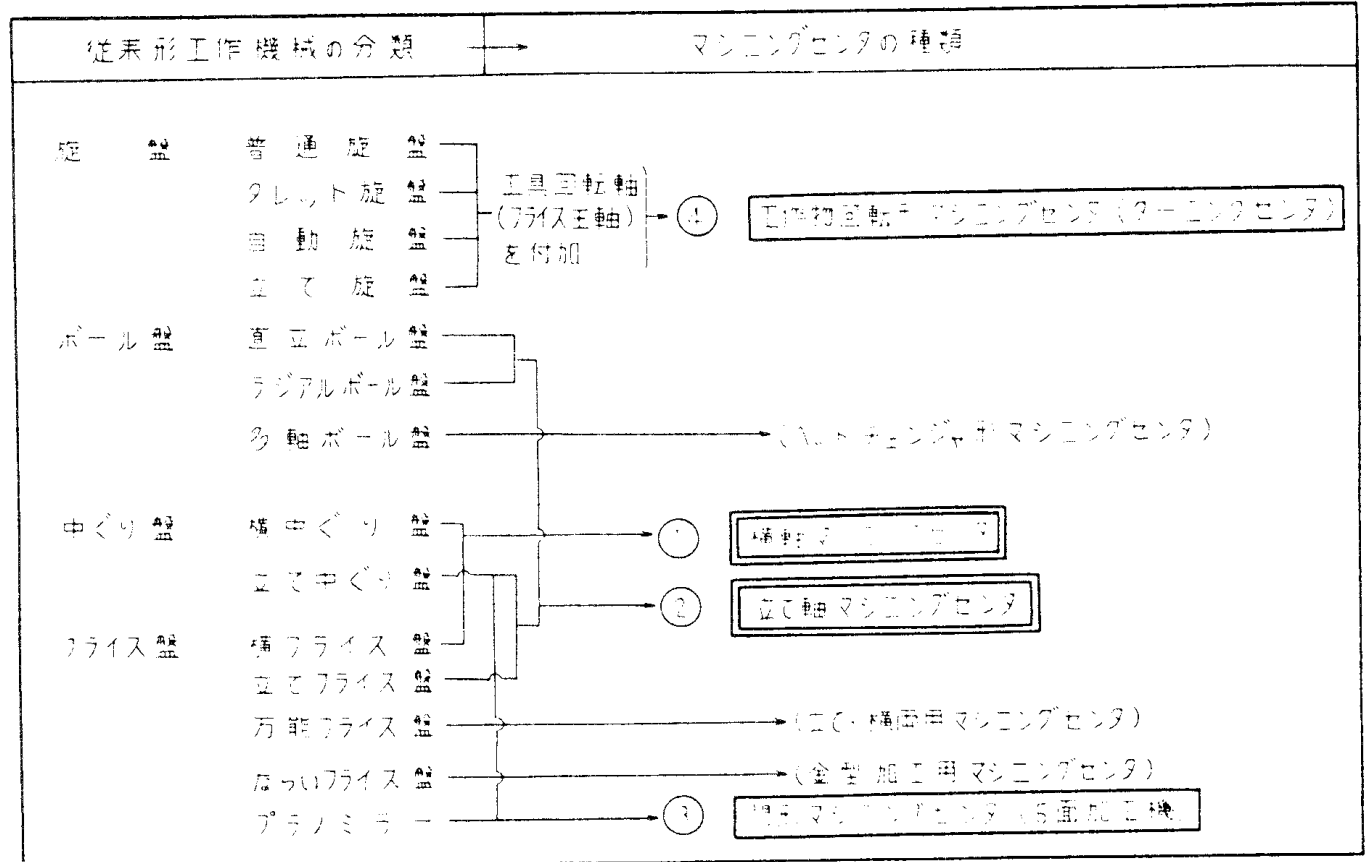

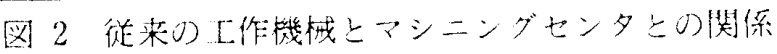




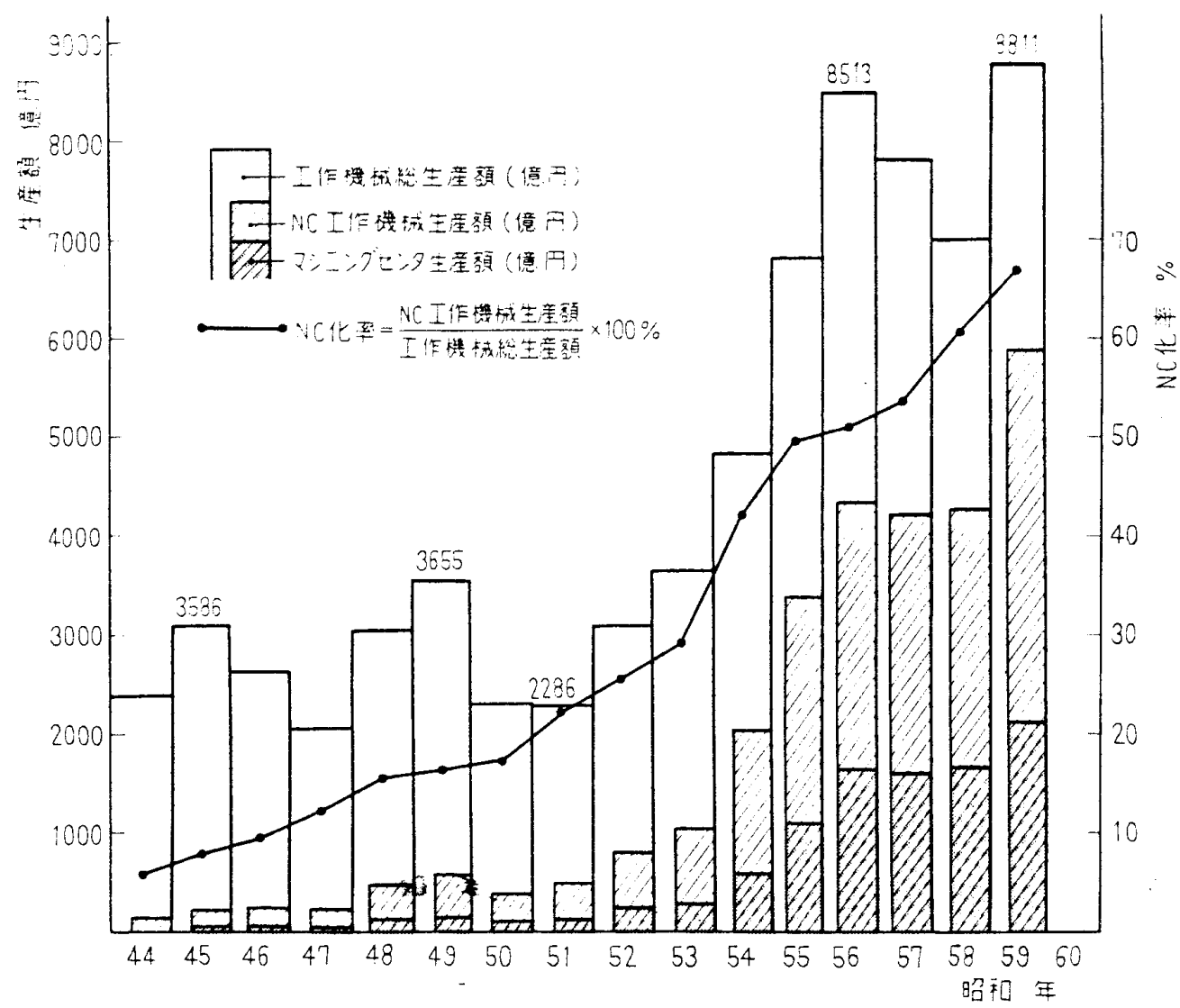

図 3 工作機械生産額の推移と NC化率

な,いわゆる「5面加工機」が注目されている。

(4) 工作物回転形マシニングセンタ 工作物 回転主軸のほかに工具回転主軸を有し, 軸類の旋 削と穴あけ，溝削り等が可能な通称ターニングセ ンタである.わが国では 1970 年ごろ出現した。

以上の 4 種類が「日本標準商品分類」に定めら れている区分であるが，このほかに多軸へッド交 換形のマシニングセンタや，ならいフライス盤か ら発展し工具の自動交換のほかに，スタイラスの 自動交換機能を有する金型加工用マシニングセン 夕等多彩である。

わが国ではこのうち横軸形及び立て軸形がほと んどで，しかも中・小形機が主体である(2)（表 1).

\section{3. マシニングセンタの需給動向}

日本の工作機械工業は，第一次オイルショック による大不況を乗り越えて昭和 50 年代に入って から高度成長を続け，生産高においては 57 年以 降連続 3 年間世界の首位の座を確保している。

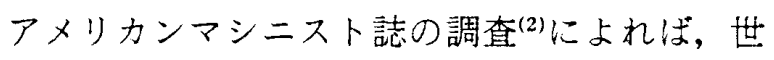
界4位の工作機械生産国であった日本は，1980 年にソ連を报いて 3 位に，1981年に西ドイツを， 1982 年にはアメリカをそれぞれ抜いてとうとう トップに踊り出たもので，1981年以降の世界的 工作機械不況のお陰とはいうものの, 日本の工作 機械業界にとっては画期的な出来事である。

なぜなら，欧米に70〜100 年も遅れてスタート し, しかも第二次世界大戦終戦後 10 年以上にも 及ぶ空白時代を経験し，技術水準は欧米に比較し て20 年もの格差があるといわれていた日本の工 作機械が，わずか 20〜30 年の短期間にここまで 量的に昖大したことは，我々はもちろん，各国に とって警異であるに違いない。

不況のどん底の年, 昭和 51 年の生産額約 2300 億円に刘し昭和 59 年は 8800 億円であるから， 約 4 倍の伸びであり，60年は 1 兆円産業の仲間 入りをするであろうと見られている。

このような成長は図 3 に見るように, NC工作 機械の㹡大に支えられていることは明らかであ る. 特に NC旋盤とマシニングセンタの増加が 
顕著であり，この両機種にメーカが集中し過酷な 販売競争を展開しているのが現状である。

$\mathrm{NC}$ 旋盤泣日本工作機械工業会会員だけで40 社, マシニングセンタ流じく 45 社が生産して

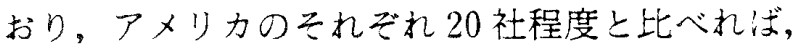
いかにたくさんのメ一カが参入しているかがわか る。

マシニングセンタメーカ4 45 社のうち，年間 500 台以上生産している企業が 8 社含まれてお り，そのうち 2 社は年産1000台在えている。 このような從来の工作機械製造体制とは異なった 量産体制を確立し，しかも多くのメーカが同形式 の類似製品で競っており，ここに不況時の過当競 争，欧米における貿易摩擦問題の原因があること は想像に難くない。自主技術による特殊性のある 機械開発が望まれているところである。

このように多過ぎるくらいのメーカと, 量産体 制とによって, 日本のマシニングセンタの生産台 数は 1980 年以降毎年5 000台以上とな朖年は 1 万台を越えた。この生産規模を欧米主要国と比 較すると図 4 のとおり，アメリカ，西ドイツは毎 年1 000 2 000 台，イギリス，フランスは 100 〜300台の水準であり, 日本の生産量がけた違い であることを示している（図 4).

昭和 51 年から 59 年までの 9 年間に生産された マシニングセンタは合計 43366 台に達するが, 図 5 に示すとおり，国内需要と輸出とが相半ばし ている(2)(诘1)。

国内需要の約 $60 \%$ は多種少量生産形態でしか も中小企業の多い「一般機械製造業」で占められ

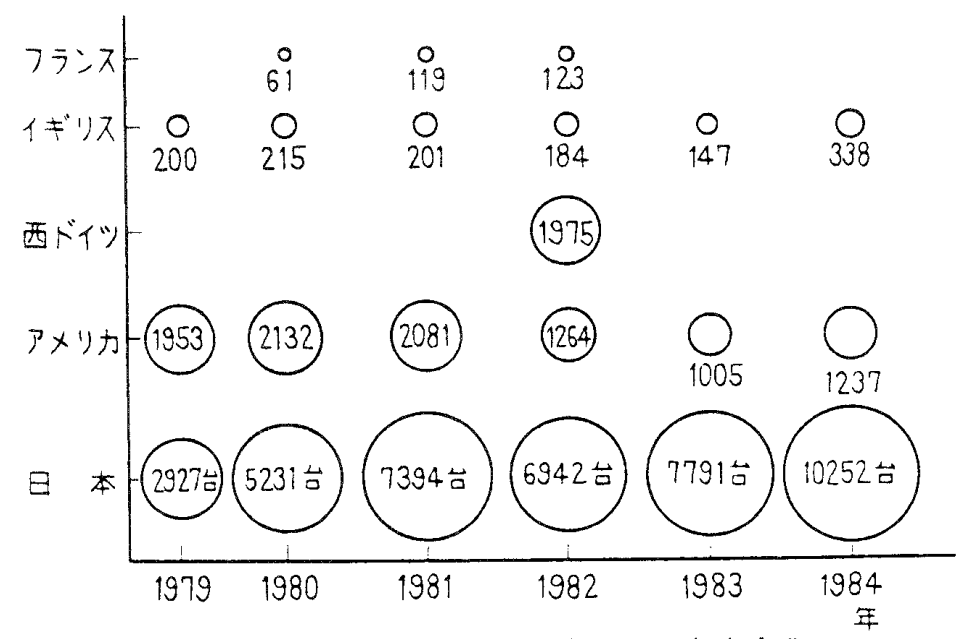

図 4 各国のマシニングセンタ生産台数

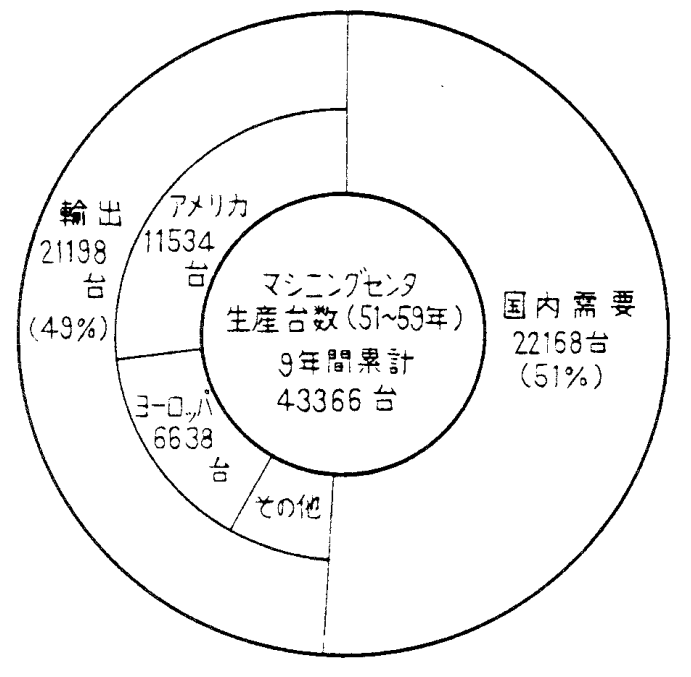

図 5 日本のマシニングセンタの出荷先 ているものと思われる。

輸出先は欧米先進国が主体で，アメリカ $54 \%$, ヨーロッパ $31 \%$ と，この両地域で $85 \%$ を占めて いる。ヨーロッパでは西ドイッ(約 2000 台), イギリス, ベルギー(それぞれ約 1000 台), フ ランス（約 700 台）等が多い. その他東南アジ ア，オーストラリア等にも輸出されている(2).

\section{4. 国産マシニングセンタの評価}

このように世界一の生産量を誇る日本のマシニ ングセン夕注国内はもちろん，欧米をはじめ世界 各国で稼動されているが，これらは各ユーザでじ のように評価されているのであろうか.

（社）日本工作機械工業会では昭和 56 年度にお いて，工業技術院からの委託事業として「マシニ ングセンタに関する標準化のための調查研 究」を実施したが，この一環として，アメ リカ, ヨーロッパのユーザを対象に, 日本 製マシニングセンタの使用状況についてア ンケート調査を行い, 18 社, 39 台分の評 価がまとめられた。。また，同じ時期に， (財)工作機械技術振與財団では, 国内ユ一 ザを対象に工作機械の技術評洒調査を実施 し，マシニングセンタについては 257 台に

（注 1）輸出は通関統計のため全数を表しているが,生 應は従業員 50 人以上の企業のみの統計（通産 省生産動態統計）であるたか少なかの数值で， 徒って国内需要进流若干多くなる。 
ついての評洒が主とられた，本章ではこれらの 調查結果を対比させながら，日本のマシニングセ ンタが，主として海外ユーザにどのように評価さ れているかについて述べる。

これらの調査結果は現状とは多少異なるかもし れない。なぜなら，調査対象機を購入した昭和 53 年〜 55 年当時は，全般的に好景気であり，工 作機械需要はおう盛で貿易摩擦問題も存在しなか つた時期であったし，またその後 3〜4年を経過 し, 日本のマシニングセンタの品質性能の向上も 顕著であると思われるからである。

$4 \cdot 1$ 購入動機・選定理由 マシニングセンタ 購入の動機は図 6 のとおり

（1）生産量の増加に対処するため

（2）自動化・省力化を推進するため

（3）製造コストの低減をはかるため

（4）製品の品質向上をはかるため が主なものであるが，アメリカでは当時の好況を 反映して「生産量の增加に対処するため和加最も 多く，次いで「省力化，自動化」となっている.

これに対し，ヨーロッパと日本のユーザは「省 力化・自動化」及び「コストの低減」が主な動機 であり, 特に日本におけるマシニングセンタの導 入は省力化投資が主体であったことがわかる。

このような購入動機に対し，なにゆえ日本のマ シニングセンタを選定したかについて，アメリカ では「納期が短い (32\%)」，ヨーロッパで「安価 である(59\%)」を第一の理由にあげているのは 興味深い.

アメリカでは前述のとおり好況下で，生産量の 増加に対処するため早く自動化機械が必要であっ たことがわかる。一方，ヨーロッパは比較的 NC 化が遅れていた時期に，日本の安価なマシニング センタに興味がもたれたのであろうか.

選定理由の中に，アメリカ，ヨーロッパとも 「精度が高いから」という項目が，それぞれ $20 \%$ 程度含まれており，日本のマシニングセン夕は決 して, 安価, 短納期だけで選ばれたのではなかっ たことに意を強くしたものである。

$4 \cdot 2$ 性能評価日本製マシニングセンタに 対する欧米及び国内ユーザの性能評価を図 7 に示 す.

評価項目として機械仕椂（速度・馬力）, 精度,
岡性, 熱特性, 信頼性, 耐久性, 自動化·省力化, 操作性, 安全性, 保守性, 価格, 及び総合評価の 12 項目（国内調査については熱特性，安全性を
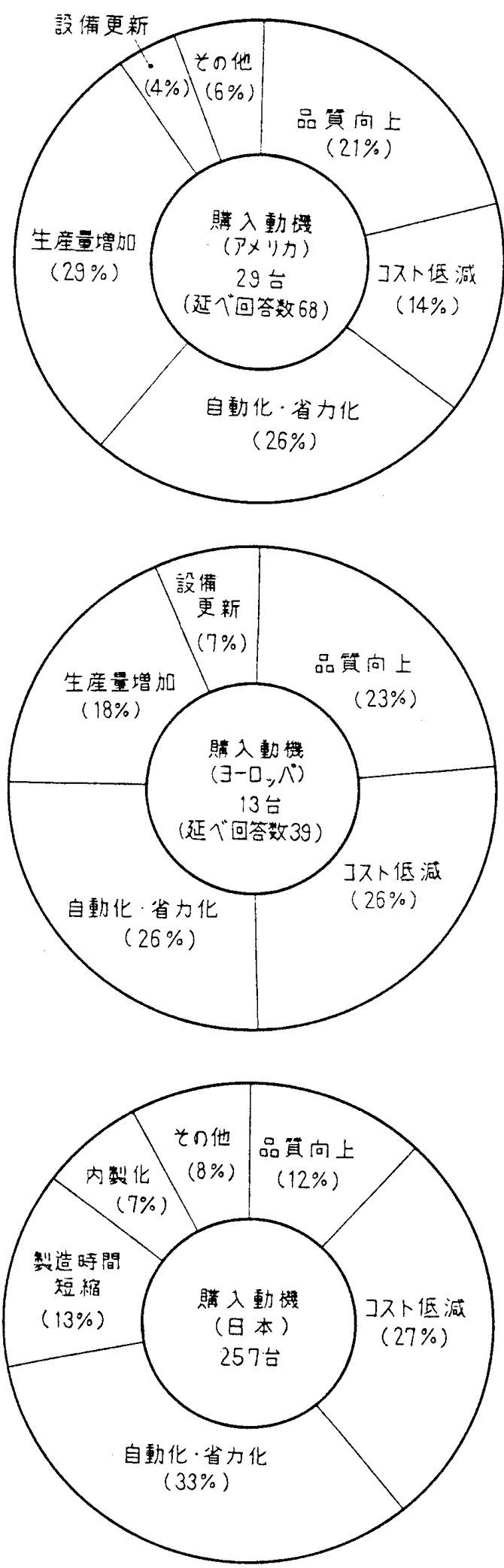

図 6 マシニングセンタの購入動機 


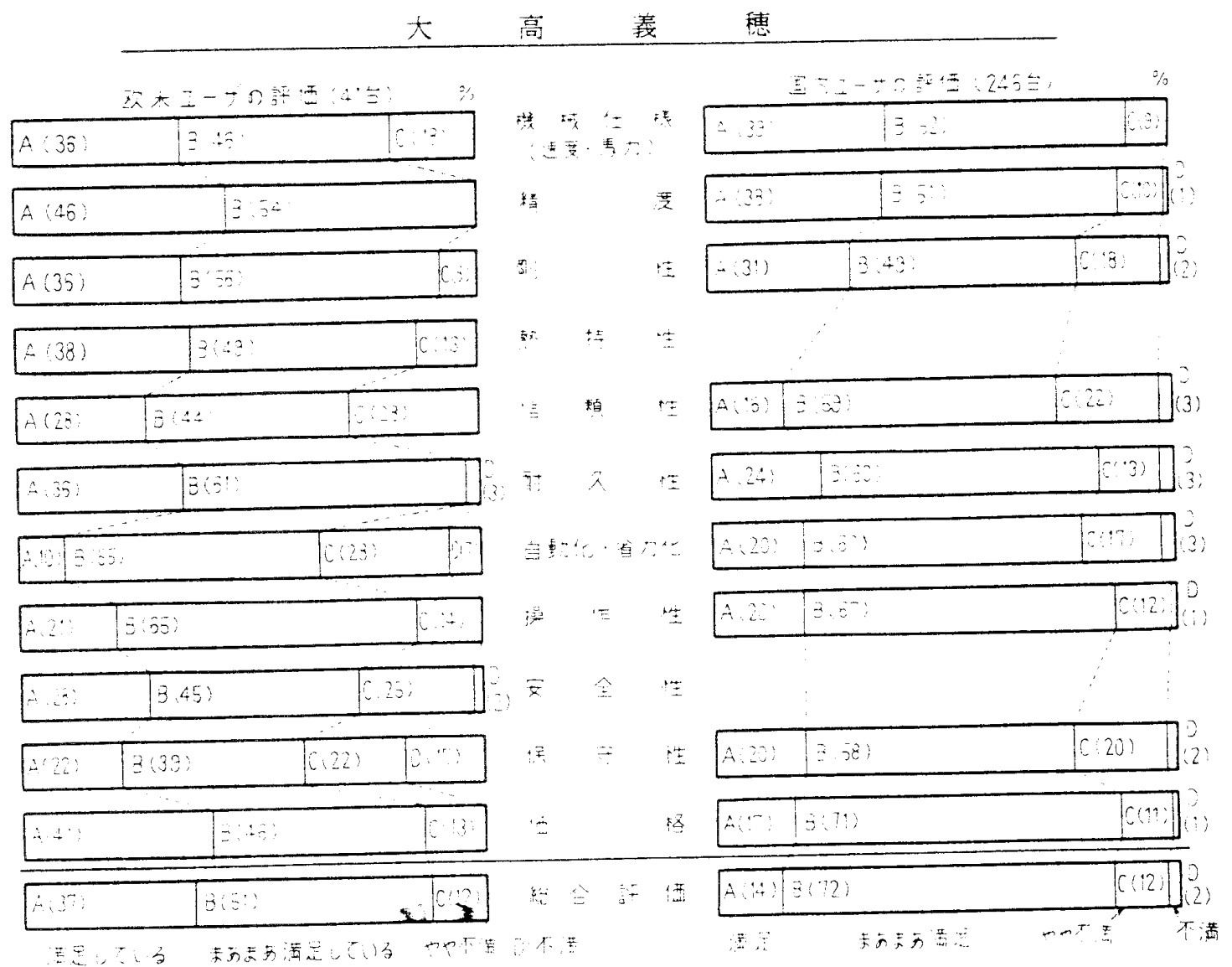

図７国産マ・シニングセンタの内外における評価

除く 10 項目)をとりあげ，それぞれについて
A：十分満足している
B：まあまあ満足している
$\mathrm{C}$ :やや不満である
$\mathrm{D}$ : 不满

の4ランクで採点してもらつたものである。

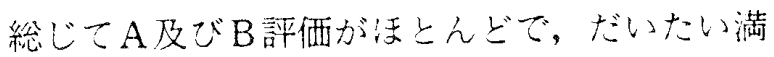
足していることがうかがわれるが，拈かいに満是 しているわけではなく，また項目によってはC， D評価が多く回答されたものもあり，今後の課題 として残されている。

欧米と日本の評洒はだいたい同じような傾向を みせているが，やはり欧米の方がシビアであり， 図では区分されていないが，アメリカよりもヨー ロッパのユーザがきびしい見方をしている．各項 目についての傾问及び間題点は以下のとおりであ る。

（1）機械仕様（速度・馬力）欧米評価の中に 「やや不満」が $18 \%$ もあり，特にヨーロッパでは $31 \%$ がCランクとしていろ。主電動機出力が不 十分であるとの回答が 3 件あった。国内ユ一ザの C評価は少ないが，マシニングセンタメーカ間格
差が大きく，某メ一力のものに対しては $29 \%$ が 「やや不満」としている。

（2）精度 日本のユーザより欧米のユーザの 方が，精度については満足している．特にアメリ 力に扩いては $58 \%$ が十分満足し，C，D評洒は みられない。ただし，導入後 $2 \sim 3$ 年めまでの評 価であり，長期間にわたって高精度が維持できる かどうかが問題であうう。

（3）剛性，熱特性 D評洒はほとんどない が，C（やや不満）とするものが若干みられる。 フライス加士や沈み座ぐり加工の際にびびり振動 が発生する，と指摘している。

日本ユーザの評価は特定 4〜 5 社のメー力に対 して低い評価を行っており，主軸の剬性不足と工 作物のびびりを訴えている。

（4）信頼性，酮久性信頼性について交内外 とも評価が良くない。欧米ではC評価が $28 \%$ も あり，特にヨーロッパでは半数近くがC評洒であ る。日本ではA（十分满足）は16\%しか評洒さ れていない、アメリカユーザから主軸の冷却シス テム不良を指摘されており，日本ユーザからはコ ントローラの故障 (25 件), 本体の故障 (14件), 
強電系の故障 ( 9 件), 付属装置等の故障 (13 件）なら゙が報告された。

耐久性について份，それ程悪い評洒ではない が，この項目岋短期間では評洒できるものではな く，導入徭 $2 \sim 3$ 年の対象機械では正確に把握で きかねたのであろう。

（5）自動化 - 省力化 内外とも極奻て評洒の 要い題目の一つである。欧米ではA評価はわずか $10 \%$ ，不満（C，D）が $35 \%$ もる。

もともと，自動化・省力化のエースとして導入 したはずが，それ程効果が上がらなかったという ことであろうか. 日本のユーザからのコメントは 大半が切りくず処理の問題に関してである.

もちろん，その後改良開発が進んでいるだろう し,マシニングセンタを中心としたシステム化 (FMS) が促進され大幅な省力化が実現している 現在, 評価は相当変わっているものと思われる.

（6）操作性・安全性操作性はA評価が少な くほとんどBである。メーカによって著ぜばら つきがあり，3社についてはA評価がなく， B と Cだけであった。アメリカからは工具監視の容易 なより良いガードの要求があった。

安全性についてはヨーロッパの評価が㒈しく, 半数以上がC (やや不満) としており，切りくず 処理，切りくずカバー不良，油もれ等を指摘して いる.

（7）保守性 欧米・日本とも最も評洒の悪い 項目である。欧米ではC及びD評価が約 $40 \%$ も

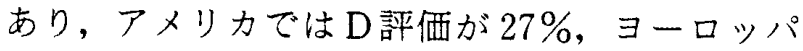
ではAがなく，C評洒が $47 \%$ に達している。

コンパクト設計が進んでいる反面, 保守管理の 困難性があるのであろうか。欧米からはスペアパ 一ツの入手困難を訴えており, 国内ユ一ザからは アフタサービスの不十分，油もれが多い等が指摘 されている。

（8）価格ささがに調査当時の価格競争力は 強く, 欧米で $41 \%$ が十分に満足していると答え ている.しかし 13\%がやや不満としていること は意外であった。

(9) 総合評価全体として日本のマシニング センタはまあまあの評価を得ているといえよう。
しかし信頼性，保守性，自動化・省力化，安全性 等の面ではいっそうの向上が必要のようである。

\section{5.むす ひ}

以上のとおり，日本のマシニングセン夕流, 様々な夕イプの機械が開発され，しかも世界一の 生産晋を誇り，世界のいたる所で稼動しているこ とがわかる。そして従来，低傮格と短納期を壳り 物にしていたのに対し，技術水準の上でもとびき り上等とはいえないまでも，一応の評価を得てい ることは明らかである。このような発展の要因を 二つ上げることができる。

一つは，マシニングセンタメ一カ各社の製造設 備の近代化, 生産技術の高度化に上り, 均一な品 質のものをより早く製造する体制を確立したこ と，第 2 はマイクロエレクトロニクス技術の利用 による高度な制御技術に依存してきたことであ る.しかし，これらのことは反面各社とも平均 的, はん用的, 類似のマシニングセンタが多く見 られるというデメリットをもたらした。

現在マシニングセンタには,ますます高精度 化，高速化への要求が強くなり，またセラミック ス等新材料の加工やFMS 化, FA 化への対応等 も求められ，いっそうの高度化が必要である。こ のためには機械本体の剛性向上や熱対策の研究， あるいは新素材の機械構造への利用なよ゙開発課題 は山積みしている。

幸いマシニングセンタの市場動向は恵まれてい るこの時期に，研究開発投資を活発にし，各社と も独自性のあるマシニングセンタを開発し，名実 ともに世界一のマシニングセンタ生産国として発 展することを期待してむすびとする。

(原稿受付 昭和 60 年 9 月 2 日)

\section{文献}

（1）工作機械-84 マシニングセンタ，(昭 59），7，大河出微.

（2）工作機械統計要覧，昭和 59 年版，(昭 60)，28，112, 212, 日本工作機械工業会.

(3) 行政管理行統計主幹, 日本標準商品分類, (昭 50 ), 303，（財）全国統㖕協会連合会。 